\title{
Communication
}

[Comunicação]

\section{Ectoparasites of Nasua nasua (Carnivora, Procyonidae) from an urban forest in Southeastern Brazil}

[Ectoparasitos de quatis Nasua nasua (Carnivora, Procyonidae) em uma floresta urbana no sudeste brasileiro]

\author{
A.F.S.F. Rodrigues ${ }^{1,4}$, E. Daemon ${ }^{2}$, C.L. Massard ${ }^{3}$ \\ ${ }^{1}$ Aluno de pós-graduação - UFRRJ - Seropédica , RJ \\ ${ }^{2}$ Departamento de Zoologia - UFJF - Juiz de Fora, MG \\ ${ }^{3}$ Departamento de Parasitologia Veterinária - UFRRJ - Seropédica, RJ \\ ${ }^{4}$ Bolsista CNPq
}

\begin{abstract}
Nasua nasua (Linnaeus, 1766) is a procionid with broad distribution in South America. The coatis are able to adjust to different environments and to eat feeding different items (Beisiegel, 2001). This behavior makes it possible for the coatis to live in urban forests, making interchanges between wild and domestic areas. The objective of this note was to report the species of ectoparasites occurring in $N$. nasua from an urban forest, Mata do Morro do Imperador, in Juiz de Fora County, Minas Gerais, Brazil. The knowledge of the ectoparasitological situation of the wild mammals in an urban forest is important to establish measures of control of the arthropods and conservation of the host.
\end{abstract}

From March 2002 to September 2004, 15 N. nasua (11 adult females, 2 young females and 2 young males) were trapped with a tomahawk-like trap baited with banana and papaya in an urban forest in Juiz de Fora County they were examined for ectoparasites after anesthetizing with xylazine and ketamine $(10 \mathrm{mg} / \mathrm{kg}$ and $20 \mathrm{mg} / \mathrm{kg}$ of body weight, respectively) (Gregg and Olson, 1975; Rodrigues et al., 1996). Other four road-killed animals (adult males) on the street around the forest were also immediatly studied. The ectoparasites were removed with a fine-comb and forceps and preserved in $70^{\circ}$ alcohol, except engorged nymphs of ticks that were maintained under controlled temperature $\left(27^{\circ} \mathrm{C}\right)$ and relative humidity $(80 \%)$ to get the adults. Lice and fleas (except Ctenocephalides felis felis) were cleared and mounted in Canada balsam on microscope slides. Adult ticks taken from nymphs were identified according to Aragão and Fonseca (1961). Fleas were identified according to Linardi and Guimarães (2000) and lices were identified according to Tuff (1977) and compared with the description of Werneck (1936). All maneuvers including capture; anesthezation, handling and releasing of the wild animals were carried out according to IBAMA (process $\mathrm{n}^{\circ}$ 0201502777/02-00) and The Ethical Committee for Animal Research (protocol $\mathrm{n}^{\circ}$ 18/2003 - CEEA-UFJF).

The infestation parameters for the species of ectoparasites collected from coatis are listed in Table 1.

Amblyomma ovale (Koch, 1844), Amblyomma cajennense (Fabricius, 1787) and Amblyomma parvum (Aragão, 1908) were reported on coati from Brazil (Aragão and Fonseca, 1961; Figueiredo et al. 1999; Labate et al., 2001) and Amblyomma collebs was obtained from a captive coati (Labate et al., 2001). No adult ticks were collected on coatis in this study. The nymphs that molted to adults were identified as $A$. cajenennse. Zerpa et al. (2003) collected only nymphs on coatis from Ecuador. The grooming among hosts can be an important behaviour to control ectoparasites, especially adult tick, a fixed and large ectoparasite.

Recebido em 11 de fevereiro de 2005

Aceito em 28 de abril de 2006

E-mail: afsfr@bol.com.br 
Table 1. Ectoparasites collected from Nasua nasua $(\mathrm{n}=19)$ in an urban forest, mata do Morro do Imperador - Juiz de Fora, MG, Southeastern Brazil, between 2002 and 2004

\begin{tabular}{|c|c|c|c|c|}
\hline Ectoparasites species & Number & $\begin{array}{c}\text { Mean intensity } \\
\pm \mathrm{SD}\end{array}$ & $\begin{array}{c}\text { Mean abundance } \\
\pm \mathrm{SD}\end{array}$ & $\begin{array}{c}\text { Prevalence } \\
(\%)\end{array}$ \\
\hline \multicolumn{5}{|l|}{ Ixodidae } \\
\hline Larvae & 24 & $3.28 \pm 3.40$ & $1.26 \pm 2.64$ & 36.8 \\
\hline $\mathrm{Nymph}^{*}$ & 41 & $3.41 \pm 2.99$ & $2.15 \pm 2.89$ & 63.1 \\
\hline \multicolumn{5}{|l|}{ Siphonaptera } \\
\hline Ctenocephalides felis felis & 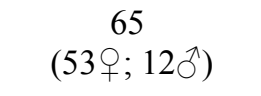 & $9.28 \pm 14.7$ & $3.42 \pm 9.66$ & 36.8 \\
\hline Rhopalopsyllus lutzi lutiz & $\begin{array}{c}7 \\
\left(3 q ; 4 \bigcirc^{\lambda}\right)\end{array}$ & $1.16 \pm 0.40$ & $0.36 \pm 0.59$ & 31.5 \\
\hline \multicolumn{5}{|l|}{ Phthiraptera } \\
\hline Neotricodectes pallidus & $\begin{array}{c}61 \\
\left(17 q ; 23 \delta^{\uparrow} ; 16 \mathrm{n}\right)\end{array}$ & $5.90 \pm 4.25$ & $3.21 \pm 4.54$ & 52.6 \\
\hline
\end{tabular}

In Brazil Ctenocephalides felis felis (Bouché, 1835), Polygenis pradoi (Wagner,1937), Rhopalopsyllus australis tamoyus (Jordan and Rothschild, 1923), Rhopalopsyllus lutzi lutzi (Baker, 1904) were reported on coatis (Linardi and Guimarães, 2000). Two species of fleas were recovered from coatis in this study, R. lutzi lutzi and $C$. felis felis. Among the fleas, C. felis felis was the most prevalent and abundant species, giving a sex ratio female: male of 4.4:1 (Tab.-1). This species was indicated as the most prevalent in Procyonidae (Labate et al. 2001). In the USA this species was also reported as the most prevalent in raccoons (Whitaker and Goff, 1979). The sex ratio of this species observed on $N$. nasua concurs with the sex ratio of the species 3:1-4:1 (Linardi and Guimarães, 2000). The high prevalence, mean intensity and sex ratio suggest that the infestation of $C$. felis felis on coati from Morro do Imperador is not accidental.

The lice Neotrichodectes pallidus (Piaget, 1880), was collected in $52.6 \%$ of the hosts (Tab.-1). This specie has been reported on coati from many states of Brazil (Werneck, 1948).

These results show that the coatis from an urban forest can maintain ectoparasites of wild environments, like $R$. lutzi lutzi and $N$. pallidus, as well as ectoparasites that can be involved in the urban environment, like immature ticks and C. felis felis, a habitual flea from dogs and cats. In the face of these data, the species of ectoparasites could be making interchange of pathogens between both areas.

Keywords: coati, Nasua nasua, ectoparasites.

\section{RESUMO}

Em um fragmento de mata na área urbana de Juiz de Fora (MG) foram capturados 15 quatis com armadilha e ceva, para estudo dos seus ectoparasitos. Outros quatro animais, atropelados no entorno, foram também examinados imediatamente após o atropelamento, e incluídos na análise. Os ectoparasitos foram removidos com a utilização de pinça e pente-fino e acondicionados em etanol $70^{\circ} \mathrm{GL}$. Pulgas e piolhos foram clarificados e montados para análise em microscopia. Os ixodideos foram identificados sob estereoscopia. Não foram encontrados carrapatos adultos. Larvas e ninfas de carrapatos foram encontradas, respectivamente, em 36,8\% e 63,1\% dos hospedeiros examinados. Ninfas que sofreram muda foram identificadas como Amblyomma 
cajenennse. A espécie de piolho Neotrichodectes pallidus foi obtida em $52,6 \%$ dos quatis. As pulgas Ctenocephalides felis felis $e$ Rhopalopsyllus lutzi lutzi apresentaram, respectivamente, as seguintes prevalências: $36,8 \%$ e $35,1 \%$. O estudo mostra que no fragmento de mata na área urbana os quatis podem manter espécies de ectoparasitos comuns a estes hospedeiros, bem como intercambia-las entre $o$ ambiente silvestre e urbano.

Palavras-chave: quati, Nasua nasua, ectoparasitos.

\section{ACKNOWLEDGMENTS}

We acknowledge the collaboration of Dr. Pedro Marcos Linardi and Michel Valim from Universidade Federal de Minas Gerais and Dr. João G. W. Brum from Universidade Federal de Pelotas. We also acknowledge CNPq, IBAMA, Universidade Federal Rural do Rio de Janeiro and Universiade Federal de Juiz de Fora.

\section{REFERENCES}

ARAGÃO, H.; FONSECA, F. Notas de Ixodologia VIII. Lista e chave para os representantes da fauna ixodológica brasileira. Mem. Inst. Oswaldo Cruz, v.59, p.115-130, 1961

BEISIEGEL, B.M. Notes on the coati Nasua nasua (Carnivora: Procionidae) in an atlantic forest area Braz. J. Biol, v.61, p.689-692, 2001.

FIGUEIREDO, L.T.M.; BADRA, S.J.; PEREIRA, L.E. et al. Report on ticks collected in Southeast and Mid-West regions of Brazil: analyzing the potential transmission of tickborne pathogens to man Rev. Soc. Bras. Med. Trop., v.32, p.613-619, 1999.

GREGG, D.A.; OLSON, L.D. The use of ketamine hydrochloride as an anesthetic for raccoons. J. Wildl. Dis., v. 11, p. 335-337, 1975.
LABATE, A.S.; NUNES, A.L.V.; GOMES, M.S., Order Carnívora, family Procionidae (raccoons, kinkajus) In: FOWLER, M.E.; CUBAS, Z.S. Biology, medicine and surgery of South American wild animals, Ames: Iowa State University Press, 2001.

LINARDI, P.M.; GUIMARÃES, L.R. Sifonápteros do Brasil. Museu de Zoologia USP/FAPESP, São Paulo, 2000. 291p.

MARGOLIS, G.; ESCH, G.W.; HOLMES, J.C. et al. The use of ecological terms in parasitology J. Parasitol., v.68, p.131-133, 1982.

RODRIGUES, R.R.; VASCONCELLOS, C.H.C.; ALMOSNY, N.R.P. et al. Determinação de hemogramas, bioqúimica sérica e pesquisa de hemoparasitos em quatis (Nasua nasua) em condições de cativeiro no Estado do Rio de Janeiro. Rev. Bras. Cienc. Vet., v.3, p.89-92, 1996.

TUFF, D.W. A key to lice of man and domestic animals Texas J. Sci., v.28, p.145-159,1977.

WERNECK, F.L., Contribuição ao conhecimento dos Mallophagos de mamíferos sul-americanos Mem. Inst. Oswaldo Cruz, v.31, p.391-589, 1936.

WERNECK, F.L., Os malófagos de mamíferos: parte 1 Amblycera e Ischnocera (Philopteridae e parte de Trichodectidae) Rev. Brasil. Biol., 1948. $243 p$.

WHITAKER, J.O.; GOFF, R., Ectoparasitos of wild carnivora of Indiana. J. Med. Entomol., v.15, p.425-430, 1979.

ZERPA, C.; KEIRANS, J.E.; MANGOLD, A.J. et al. Confirmation of the presence of Amblyomma ovale Koch 1844 and first records of Amblyomma scalpturatum Neumann 1906 (Acari: Ixodida: Ixodidae) in the amazonian region of ecuador. Proc. Entomol. Soc. Wash., v. 105, p. $783-785,2003$ 